\title{
Low and High Nitrogen Deposition Rates in Northern Coniferous Forests Have Different Impacts on Aboveground Litter Production, Soil Respiration, and Soil Carbon Stocks
}

\author{
Benjamin Forsmark, ${ }^{1 *} \odot$ Annika Nordin, ${ }^{2}$ Nadia I. Maaroufi, ${ }^{3,4}$ \\ Tomas Lundmark, ${ }^{1}$ and Michael J. Gundale ${ }^{1}$
}

\footnotetext{
${ }^{1}$ Department of Forest Ecology and Management, Swedish University of Agricultural Sciences, 90736 Umeå, Sweden; ${ }^{2}$ Department of Forest Genetics and Plant Physiology, Umea Plant Science Center, Swedish University of Agricultural Sciences, 90736 Umea, Sweden; ${ }^{3}$ Department of Forest Mycology and Plant Pathology, Swedish University of Agricultural Sciences, 75007 Uppsala, Sweden; ${ }^{4}$ Institute of Plant Sciences, University of Bern, 3013 Bern, Switzerland
}

\begin{abstract}
Nitrogen $(\mathrm{N})$ deposition can change the carbon $(\mathrm{C})$ sink of northern coniferous forests by changing the balance between net primary production and soil respiration. We used a field experiment in an $\mathrm{N}$ poor Pinus sylvestris forest where five levels of $\mathrm{N}(0$, $3,6,12$, and $50 \mathrm{~kg} \mathrm{~N} \mathrm{ha}^{-1} \mathrm{yr}^{-1}, n=6$ ) had been added annually for $12-13$ years to investigate how litter $\mathrm{C}$ inputs and soil respiration, divided into its autotrophic and heterotrophic sources, respond to different rates of $\mathrm{N}$ input, and its subsequent effect on soil $\mathrm{C}$ storage. The highest $\mathrm{N}$ addition rate
\end{abstract}

Received 6 March 2019; accepted 26 December 2019; published online 23 January 2020

Electronic supplementary material: The online version of this article (https://doi.org/10.1007/s10021-020-00478-8) contains supplementary material, which is available to authorized users.

Author Contributions: BF, MG, AN, and NM conceived the study, AN initiated the field experiment, and $\mathrm{BF}, \mathrm{AN}, \mathrm{MG}, \mathrm{NM}$, and TL contributed to the study design and made essential contributions to the field research. $\mathrm{BF}$ and MG analyzed the data and BF was the lead writer and MG, AN, NM, and TL co-wrote the manuscript.

*Corresponding author; e-mail: benjamin.forsmark@slu.se
(50 $\mathrm{kg} \mathrm{N} \mathrm{ha}^{-1} \mathrm{yr}^{-1}$ ) stimulated soil $\mathrm{C}$ accumulation in the organic layer by $22.3 \mathrm{~kg} \mathrm{C} \mathrm{kg}^{-1} \mathrm{~N}$ added, increased litter inputs by $46 \%$, and decreased soil respiration per mass unit of soil C by $31.2 \%$, mainly by decreasing autotrophic respiration. Lower $\mathrm{N}$ addition rates $\left(\leq 12 \mathrm{~kg} \mathrm{~N} \mathrm{ha}^{-1} \mathrm{yr}^{-1}\right.$ ) had no effect on litter inputs or soil respiration. These results support previous studies reporting on increased litter inputs coupled to impeded soil C mineralization, contributing to enhancing the soil $\mathrm{C}$ sink when $\mathrm{N}$ is supplied at high rates, but add observations for lower $\mathrm{N}$ addition rates more realistic for $\mathrm{N}$ deposition. In doing so, we show that litter production in $\mathrm{N}$ poor northern coniferous forests can be relatively unresponsive to low $\mathrm{N}$ deposition levels, that stimulation of microbial activity at low $\mathrm{N}$ additions is unlikely to reduce the soil $\mathrm{C}$ sink, and that high levels of $\mathrm{N}$ deposition enhance the soil $\mathrm{C}$ sink by increasing litter inputs and decreasing soil respiration. 
Key words: autotrophic respiration; boreal forest; carbon budget; carbon sequestration; heterotrophic respiration; nitrogen deposition; soil carbon pools and fluxes; soil respiration.

\section{Highlights}

- The high $\mathrm{N}$ treatment increased soil $\mathrm{C}$ stocks by $22.3 \mathrm{~kg} \mathrm{C} \mathrm{kg} \mathrm{N}^{-1}$ added.

- The high $\mathrm{N}$ treatment increased litter production and decreased soil respiration.

- Low $\mathrm{N}$ treatments did not impact litter production, soil respiration, or C stocks.

\section{INTRODUCTION}

Net primary productivity (NPP) in northern coniferous forests is often limited by the low availability of nitrogen (N) (LeBauer and Treseder 2008; Tamm 1991; Vitousek and others 1997). During the last century, $\mathrm{N}$ availability has increased in many ecosystems as a consequence of the extensive use of fossil fuels and industrial $\mathrm{N}_{2}$ fixation (Galloway and others 2008; Reay and others 2008). Deposition of $\mathrm{N}$ in northern coniferous forests has the potential to increase uptake of carbon (C) in vegetation and thus counteract the ongoing rise in atmospheric $\mathrm{CO}_{2}$ concentration (Houle and Moore 2008), but the importance of this effect for the global $\mathrm{C}$ balance has been debated for decades (de Vries 2009; de Vries and others 2008; Holland and others 1997; Magnani and others 2007; Myneni and others 2001). The controversy can be ascribed to two key sources of uncertainty. First, $\mathrm{N}$ addition experiments typically apply one order of magnitude more $\mathrm{N}$ than current upper $\mathrm{N}$ deposition rates in northern coniferous forests, making it uncertain if the NPP responses are applicable to the range of relatively low inputs of $\mathrm{N}$ deposition (de Vries and others 2014; From and others 2016; Hyvönen and others 2008; Nohrstedt 2001). Second, most of the $\mathrm{C}$ in northern coniferous forests is stored in soils, yet little is known about how different levels of $\mathrm{N}$ deposition will impact soil $\mathrm{C}$ pools and fluxes (Janssens and others 2010; Olsson and others 2009). Although increasing NPP will likely increase soil C stocks by increasing aboveground litter inputs, it remains highly uncertain how $\mathrm{N}$ affects the emissions of $\mathrm{C}$ back into the atmosphere via soil respiration and how these fluxes are affected by low versus high levels of $\mathrm{N}$ inputs (Bowden and others 2004; Hasselquist and others 2012; Peng and others 2017). Quantification of the effect of different rates of $\mathrm{N}$ addition on the main inputs and outputs of $\mathrm{C}$ to soils is therefore needed to better predict changes in the $\mathrm{C}$ sink of northern coniferous forests receiving different levels of $\mathrm{N}$ deposition.

Differences in $\mathrm{N}$ demand between plants and soil microorganisms are likely to play an important role in regulating soil $\mathrm{C}$ fluxes at different rates of $\mathrm{N}$ inputs (Kaye and Hart 1997; Kuzyakov and Xu 2013). Trees allocate a substantial part of their $C$ belowground to roots and root-associated microbes involved in nutrient acquisition, especially when the availability of $\mathrm{N}$ is low (Hermans and others 2006; Litton and others 2007; Mäkelä and others 2008). This C flux is an important driver of soil respiration (that is, autotrophic $\mathrm{CO}_{2}$ efflux) (Chen and others 2014) and also contributes to decomposition processes (Kuzyakov 2010; Talbot and others 2008). When $\mathrm{N}$-limited trees are supplied with high amounts of $\mathrm{N}$, a reduction in $\mathrm{C}$ allocation to $\mathrm{N}$ acquisition could enable a higher aboveground growth, leading to an increase in aboveground litter inputs, while the autotrophic respiration could remain the same, or decrease (Chen and others 2014; Litton and others 2007; Vicca and others 2012). At lower N supply, however, soil microbes including root-associated mycorrhizal fungi are also likely to be $\mathrm{N}$ limited and stimulated by the increase in $\mathrm{N}$ availability, leading to increased autotrophic respiration (Franklin and others 2014; Hasselquist and others 2012; Janssens and others 2010). Despite that most northern coniferous forest is strongly $\mathrm{N}$ limited and also receives very low $\mathrm{N}$ deposition levels (Gundale and others 2011), few studies have simultaneously assessed the impact of different rates of $\mathrm{N}$ input on the major $\mathrm{C}$ fluxes (de Vries and others 2014).

In addition to autotrophic soil respiration that is linked to plant $\mathrm{C}$ allocation, a substantial portion of C emission from forest soils is derived from saprotrophic activity (that is, heterotrophic respiration) (Hanson and others 2000; Högberg and others 2001) and may respond more directly to changes in $\mathrm{N}$ availability (Janssens and others 2010). Most studies evaluating $\mathrm{N}$ effects on saprotrophic activity have found decreased heterotrophic respiration ($15 \%$ ) (Janssens and others 2010), decomposition (Ågren and others 2013; Fog 1988; Knorr and others 2005), and microbial biomass (Treseder, 2008), all of which typically decrease in response to high $\left(\geq 20 \mathrm{~kg} \mathrm{~N} \mathrm{ha}^{-1} \mathrm{y}^{-1}\right) \mathrm{N}$ addition rates. In contrast, the impact of lower $\mathrm{N}$ addition rates ( $\leq 12 \mathrm{~kg} \mathrm{~N} \mathrm{ha}^{-1} \mathrm{y}^{-1}$ ), which is more relevant for 
Table 1. Summary of Stand Properties in Response to Different Levels of Long-term Nitrogen Additions (0, $3,6,12$, and $50 \mathrm{~kg} \mathrm{~N} \mathrm{ha}^{-1} \mathrm{y}^{-1}$ ).

\begin{tabular}{|c|c|c|c|c|c|}
\hline & \multicolumn{5}{|c|}{ Nitrogen treatment } \\
\hline & $0 \mathrm{~N}$ & $3 \mathrm{~N}$ & $6 \mathrm{~N}$ & $12 \mathrm{~N}$ & $50 \mathrm{~N}$ \\
\hline $\begin{array}{l}\text { Annual (cumulative) nitrogen addition } \\
\qquad\left(\mathrm{kg} \mathrm{ha}^{-1}\left(\mathrm{y}^{-1}\right)\right)\end{array}$ & Control $(0)$ & $3(39)$ & $6(78)$ & $12(156)$ & $50(650)$ \\
\hline \multicolumn{6}{|l|}{ Tree layer properties } \\
\hline Stem density $\left(n \mathrm{ha}^{-1}\right)$ & $472( \pm 61)$ & $476( \pm 33)$ & $558( \pm 104)$ & $483( \pm 112)$ & $540( \pm 58)$ \\
\hline Basal area $\left(\mathrm{m}^{2} \mathrm{ha}^{-1}\right)$ & $25.2( \pm 2.5)$ & $22.3( \pm 1.7)$ & $23.7( \pm 1.3)$ & $25.9( \pm 1.8)$ & $25.8( \pm 1.4)$ \\
\hline $\begin{array}{l}\text { Change in basal area } 2005-2014 \\
\left(\mathrm{~m}^{2} \mathrm{ha}^{-1}\right)\end{array}$ & $1.10( \pm 0.10)$ & $1.05( \pm 0.04)$ & $1.21( \pm 0.15)$ & $1.25( \pm 0.16)$ & $2.23( \pm 0.14)$ \\
\hline $\begin{array}{l}\text { Foliage nitrogen concentration } 2014 \\
\text { (mass\%) }\end{array}$ & $1.16( \pm 0.04)$ & $1.16( \pm 0.05)$ & $1.16( \pm 0.06)$ & $1.15( \pm 0.02)$ & $1.4( \pm 0.09)$ \\
\hline \multicolumn{6}{|l|}{ Forest floor vegetation } \\
\hline Ericaceous shrubs & $205( \pm 12)$ & $264( \pm 20)$ & $256( \pm 12)$ & $304( \pm 20)$ & $269( \pm 22)$ \\
\hline Bryophytes & $213( \pm 18)$ & $179( \pm 22)$ & $201( \pm 13)$ & $209( \pm 17)$ & $108( \pm 15)$ \\
\hline Lichens & $168( \pm 6)$ & $174( \pm 8)$ & $169( \pm 5)$ & $159( \pm 11)$ & $139( \pm 8)$ \\
\hline Total & $582( \pm 13)$ & $616( \pm 19)$ & $626( \pm 11)$ & $672( \pm 17)$ & $515( \pm 17)$ \\
\hline \multicolumn{6}{|l|}{ Soil chemistry } \\
\hline $\begin{array}{l}\text { Organic layer nitrogen concentration } \\
\qquad(\mathrm{C}: \mathrm{N})\end{array}$ & $44.0( \pm 1.27)$ & $41.9( \pm 1.20)$ & $41.7( \pm 1.84)$ & $41.2( \pm 1.14)$ & $35.6( \pm 1.02)$ \\
\hline Organic layer $\mathrm{pH}$ & $3.3( \pm 0.06)$ & $3.2( \pm 0.04)$ & $3.3( \pm 0.03)$ & $3.2( \pm 0.03)$ & $3.1( \pm 0.04)$ \\
\hline Mineral $0-10 \mathrm{~cm} \mathrm{pH}$ & $4.0( \pm 0.05)$ & $4.0( \pm 0.03)$ & $4.1( \pm 0.06)$ & $4.0( \pm 0.05)$ & $3.9( \pm 0.04)$ \\
\hline Mineral $10-20 \mathrm{~cm} \mathrm{pH}$ & $4.4( \pm 0.07)$ & $4.5( \pm 0.06)$ & $4.4( \pm 0.06)$ & $4.5( \pm 0.07)$ & $4.4( \pm 0.07)$ \\
\hline
\end{tabular}

pH determined in $\mathrm{CaCl}_{2}$

Treatments consisted of annual addition of ammonium nitrate beginning in 2004. Tree layer properties were measured eight years after the experiment started and are reported in From and others (2016). The forest floor vegetation layer is the average number of pinpoint hits per $m^{2}$, a measure of relative abundance, of eight floral surveys 2004-2015 period using the point intercept method, as described in Strengbom and others (2002). All values are means of six replicate plots ( \pm standard error).

understanding $\mathrm{N}$ deposition effects in northern coniferous forests, remains less understood. Lower rates of $\mathrm{N}$ input may have the opposite effects to high $\mathrm{N}$ addition rates by alleviating $\mathrm{N}$ limitations on saprotrophic activity, which could lead to increased emissions of $\mathrm{CO}_{2}$ via heterotrophic soil respiration (de Vries and others 2014; Knorr and others 2005). If soil microbial communities, including both freeliving saprotrophs and root-associated mycorrhizal fungi, are actually $\mathrm{N}$ limited, they could immobilize into their biomass the relatively low amounts of $\mathrm{N}$ inputs that are typical of the northern coniferous forests $\left(1-12 \mathrm{~kg} \mathrm{~N} \mathrm{ha}^{-1} \mathrm{y}^{-1}\right.$; Gundale and others 2011), which could subsequently increase their activity and limit plant access to that N. Enhanced saprotrophic activity in response to low levels of $\mathrm{N}$ deposition would result in higher respiration rates and potentially also lower $\mathrm{C}$ accumulation rates than demonstrated in high-level $\mathrm{N}$ addition experiments (de Vries and others 2014; Knorr and others 2005).

We used a long-term (12-13 years) replicated $(n=6)$ experiment designed to simulate a gradient of $\mathrm{N}$ deposition rates $\left(0,3,6,12\right.$, and $50 \mathrm{~kg} \mathrm{~N}^{-}$ $\left.{ }^{1} \mathrm{y}^{-1}\right)$ to better understand how litter $\mathrm{C}$ inputs and
C outputs via soil respiration respond to different rates of $\mathrm{N}$ input and further to investigate its subsequent effect on soil $\mathrm{C}$ accumulation. The experiment is located in a region where $\mathrm{N}$ deposition is low (ca. $2 \mathrm{~kg} \mathrm{~N} \mathrm{ha}^{-1} \mathrm{y}^{-1}$ ), thereby allowing us to evaluate the effects of lower $\mathrm{N}$ addition rates on $\mathrm{C}$ dynamics than has been done in most previous studies. We measured the input of $\mathrm{C}$ from aboveground litter and the output of $\mathrm{C}$ via soil respiration. We used root isolation treatments, that is, trenches, to further isolate the impact of $\mathrm{N}$ on the heterotrophic versus autotrophic contribution to soil respiration. First, we hypothesized that a shift in tree $\mathrm{C}$ allocation from below to aboveground structures in response to $\mathrm{N}$ additions would result in increased litter inputs and decreased autotrophic soil respiration. Further, we anticipated that these changes would occur only at high levels of $\mathrm{N}$ addition (50 $\mathrm{kg} \mathrm{N} \mathrm{ha}^{-1} \mathrm{y}^{-1}$ ) because trees are likely to have greater access to external $\mathrm{N}$ inputs when it is applied at high rates (Gundale and others 2011; Kaye and Hart 1997). Second, we hypothesized that high levels of $\mathrm{N}$ addition would decrease heterotrophic respiration due to inhibitory effects on soil saprotrophs (Fog 1988), whereas low levels 
of $\mathrm{N}$ addition $\left(<12 \mathrm{~kg} \mathrm{~N} \mathrm{ha}^{-1} \mathrm{y}^{-1}\right)$ would increase both heterotrophic respiration and autotrophic respiration by alleviating $\mathrm{N}$ limitations on saprotrophic and mycorrhizal activity (de Vries and others 2014). Collectively, we anticipated that changes in these major inputs and outputs of $\mathrm{C}$ to the soil would help explain the effect of different rates of $\mathrm{N}$ addition on soil $\mathrm{C}$ storage and that testing these hypotheses together would provide a more mechanistic understanding of the impact of $\mathrm{N}$ deposition on the soil $\mathrm{C}$ sink of northern coniferous forests.

\section{Materials ANd Methods}

\section{Site and Treatments}

We used a forest $\mathrm{N}$ addition experiment at Åheden in the Svartberget research forest $\left(64^{\circ} 13^{\prime} \mathrm{N}, 19^{\circ}\right.$ $48^{\prime} \mathrm{E}$ ) in inland northern Sweden designed to simulate $\mathrm{N}$ deposition (Table 1). The experiment is located in a region with very low $\mathrm{N}$ deposition $\left(<2 \mathrm{~kg} \mathrm{~N} \mathrm{ha}^{-1} \mathrm{y}^{-1}\right.$ (Karlsson and others 2012)). The mean annual temperature is $+1{ }^{\circ} \mathrm{C}$ and mean annual precipitation $600 \mathrm{~mm}$. The forest stand at the experimental site is dominated by Scots pine (Pinus sylvestris L.), which naturally regenerated after a forest fire, and was by the time of this study c. 140 years old (From and others 2016). The soil at the site is developed on an alluvial sand-silt plain and classified as a Typic Haplocryod (FAO Cambic Podzol). The forest floor is covered with a sparse layer of Ericaceous shrubs, including Vaccinium vitis-idea and Calluna vulgaris, Cladina and Cladonia spp. lichens, and the mosses Pleurozium schreberi (Brid.) Mitt, and Dicranum spp. (Gundale and others 2011). Scots pine is one of the dominant tree species in the northern coniferous forests of Eurasia, and in Sweden, it constitutes $39.2 \%$ of the forest tree volume (Fransson 2017). The dry sites characteristics of our experiment site also share similarities with dry pine forests in the boreal region of North America, for example, P. banksiana (Bonan 1989).

Nitrogen treatments at five levels were assigned to 0.1 ha plots in a randomized block design $(n=6)$. Treatments commenced in 2004 (Table 1) with $\mathrm{N}$ additions at $0,3,6,12$, and $50 \mathrm{~kg} \mathrm{~N}^{-1} \mathrm{y}^{-}$ ${ }^{1}$ (hereafter referred to as $0 \mathrm{~N}, 3 \mathrm{~N}, 6 \mathrm{~N}, 12 \mathrm{~N}$, and $50 \mathrm{~N}$, respectively) in the form of solid ammonium nitrate granules evenly distributed directly applied after snowmelt each year. The low doses $(3 \mathrm{~N}, 6 \mathrm{~N}$, and $12 \mathrm{~N}$ ) simulate a gradient of $\mathrm{N}$ deposition from central to southern Fennoscandia, whereas the high $\mathrm{N}$ treatment $(50 \mathrm{~N})$ simulates upper $\mathrm{N}$ depo- sition rates in central Europe and also serves as a useful comparison with other $\mathrm{N}$ addition experiments.

To separate the effects of $\mathrm{N}$ on total soil respiration into its source components, that is, heterotrophic and autotrophic soil respiration (inclusive of tree roots and their associated microorganisms), we established root trenching treatments within each $\mathrm{N}$ addition plot (Hanson and others 2000; Maaroufi and others 2019). Each main plot was split into four equal-sized quadrat subplots, and two of the subplots were assigned to the trenching treatment, whereas the other two remained untrenched (Figure S1). Trenching was done by permanently inserting $50 \times 50 \mathrm{~cm}$ steel frames reaching $50 \mathrm{~cm}$ into the soil in July 2014, 2 years before the first measurements in this study. The $\mathrm{C}$ stock in fine-root biomass at Åheden is around $900 \mathrm{~kg} \mathrm{ha}^{-1} \quad$ (Scarascia-Mugnozza and others 2000), and we assume that the contribution of severed roots to soil respiration inside the frames was short-lived and negligible by the time we began our measurements in 2016. One frame was installed in the middle of each of the two subplots assigned to the trenching treatment. We removed any tree seedlings that were established in the frames to maintain the absence of processes associated with the tree root zone, whereas the very sparse forest floor vegetation at this site was left intact to minimize disturbance to these permanent plots. Studies have shown that the forest floor vegetation has a negligible effect on soil respiration rates (Bond-Lamberty and others 2011). In a parallel study focused on microbial community composition, we confirmed that the trenching treatment was successful at greatly reducing fungal phospholipid fatty acid concentrations, as well as DNA sequences of ectomycorrhizal fungi (Maaroufi and others 2019), indicating that the trenching treatment was successful at excluding soil communities associated with tree roots. We further assume that the 2 years that elapsed since the trenching treatment provided sufficient time to minimize the influence of the disturbance caused by the installation of the steel frames (Hanson and others 2000).

\section{Soil Carbon Stocks}

The organic layer and upper $20 \mathrm{~cm}$ of the mineral soil were sampled in late July 2017 at ten predefined locations on each main plot, outside the steel frames (Figure S1). We confined our sampling to the organic layer and mineral soil down to $20 \mathrm{~cm}$ because previous studies in similar systems have 
shown that the majority of roots and $\mathrm{C}$ are located within this depth range (Helmisaari and others 2007; Maaroufi and others 2015). The organic layer was sampled by collecting the forest floor down to the mineral soil surface with a 10-cm-diameter PVC tube fitted with a serrated blade. Mineral soil samples were then collected from the exposed mineral soil surface using a sharp steel corer at 0$10 \mathrm{~cm}$ and $10-20 \mathrm{~cm}$ depth. Parent material was reached in many places at $10-20 \mathrm{~cm}$ depth; thus, our sampling covered a majority of the soil C stock in each plot. The ten cores from each depth were pooled to form one composite sample for each depth within each plot. The composite samples were subsequently sieved $(2 \mathrm{~mm})$ to remove intact roots and thoroughly homogenized. A subsample of each composite sample was dried at $65^{\circ} \mathrm{C}$ and ground to a fine powder using a custom-made roller mill (Stuiver and others 2015), and soil C concentrations were then estimated by mass spectrometry (DeltaV IRMS coupled to a Flash EA 2000, Thermo Fisher Scientific, Bremen, Germany) with duplicate subsamples. Organic layer C stocks were calculated as the $\mathrm{C}$ concentration multiplied with the dry mass of the sample and finally divided with the total area sampled. Mineral soil C stocks were calculated by multiplying the $\mathrm{C}$ concentration with the mass of the specific soil volume, based on sitespecific bulk density estimates (Persson and others 2000). All masses were expressed on a per hectare basis, without correction for stoniness because stones were completely absent at this site. Annual $\mathrm{C}$ accumulation in the organic layer was estimated as the difference in soil $\mathrm{C}$ stocks between the average of the control treatments and each plot, divided by the duration of the $\mathrm{N}$ treatments (13 years).

\section{Litter Input}

Aboveground litter production was estimated using the standard methodology in Ukonmaanaho and others (2016). Five plastic trays $\left(0.36 \mathrm{~m}^{2}\right.$ with drainage holes) per plot were installed to collect litter continuously from May 2016 to May 2018. Trays were emptied every second month during the growing season and after the winter in May 2017 and 2018. Litter was defined as tree litter, including twigs and branches up to $20 \mathrm{~mm}$ thick and annual litter $C$ input calculated as the average of the annual sum of the mass of each collection of litter and then multiplied by a litter C concentration of $50 \%$ (Gundale and others 2014; Sandström and others 2007). Coarse woody debris was assumed to be equal across treatments and therefore does not contribute to treatment differences in litter $\mathrm{C}$ input. Similarly, the forest floor vegetation biomass at this site is low compared to other forests in this region, for example, Maaroufi and others (2016), and thus was assumed to have contributed a negligible quantity of litter compared to trees.

\section{Soil Respiration}

Emissions of $\mathrm{C}$ by soil respiration were measured as the efflux of $\mathrm{CO}_{2}$ at the soil surface using dark and sealed chambers (Pumpanen and others 2004) at permanent measurement locations inside and outside the steel frames (Figure S1). Each of the measurement locations consisted of a cylindrical 12.5-cm-high and 25-cm-wide $\left(0.05 \mathrm{~m}^{2}, 6 \mathrm{l}\right) \mathrm{PVC}$ collar installed in a predefined location in May 2016, 6 weeks before the first measurement. The collars were gently installed on top of the moss and the intact litter layer and sealed from the outside with a thin rim of sand. The height of each collar was then recorded in four cardinal directions to estimate the collar-specific volume. All aboveground living biomasses of mosses and shrubs were removed to avoid their contribution to $\mathrm{CO}_{2}$ fluxes. Five collars were installed systematically, spaced at least four meters apart outside the steel frames, whereas space limitations allowed only one collar inside each of the two steel frames within each main plot. In total, 210 collars were used, which included five outside the steel frames and two inside, in each of the 30 main plots. This design allowed us to estimate the effect of $\mathrm{N}$ on total soil respiration (outside steel frames) as well as on soil without tree roots, that is, heterotrophic respiration only (inside steel frames) which further allowed us to estimate the contribution of tree roots and their associated microbiota, which we hereafter refer to as autotrophic respiration, by subtraction (outsideinside steel frames). The separation of the total respiration into component fluxes was validated in a separate study showing that the trenching treatment did not affect humus mass loss (Maaroufi and others 2019). Differences in soil C stocks could potentially confound conclusions on the impact of $\mathrm{N}$ on soil respiration. To control for this, we also estimated the total and the heterotrophic respiration per mass unit of soil $\mathrm{C}$ by dividing the flux with the sum of $C$ stocks in the upper $20 \mathrm{~cm}$ of the soil, including the organic and the mineral layers.

Measurements were started in July 2016 and continued to October (five measurement occasions) and were repeated from June to October 2017 (six occasions) with approximately threeweek intervals (11 occasions in total). At each 


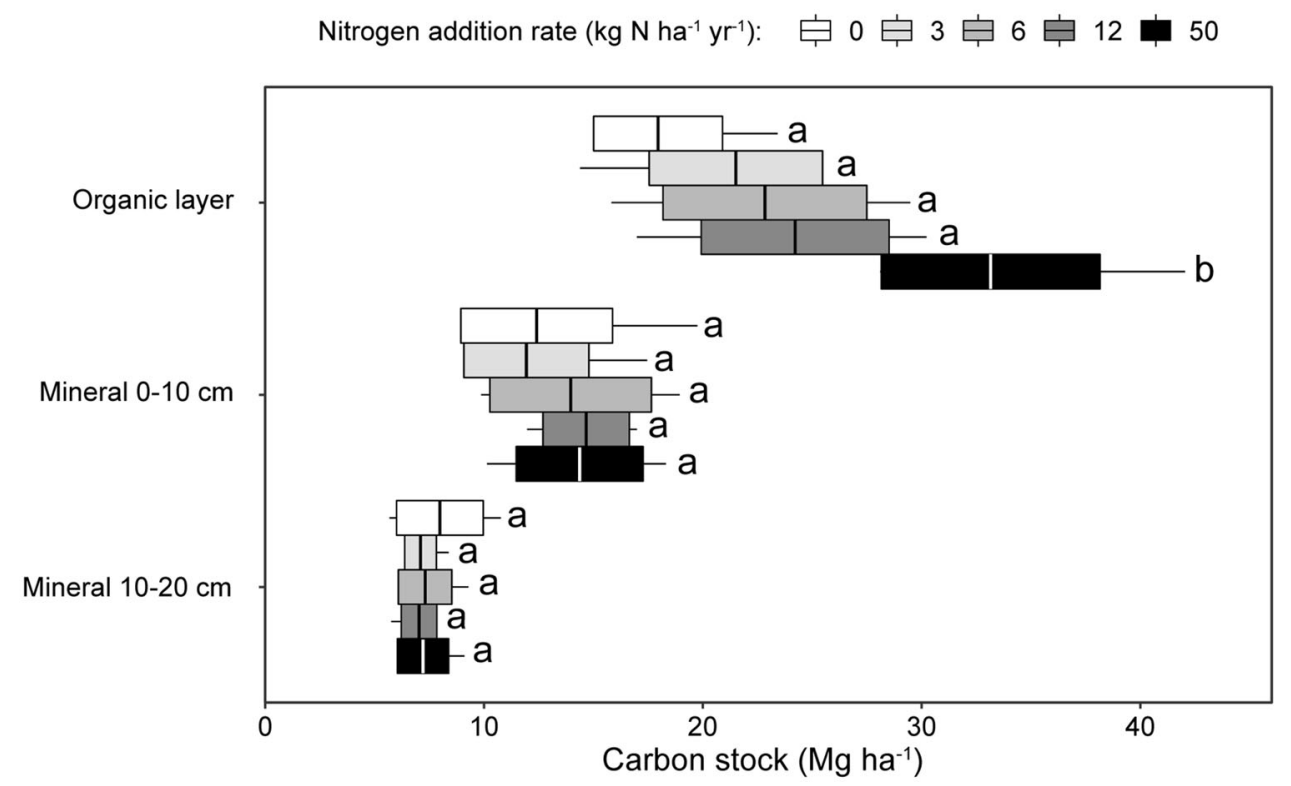

Figure 1. The soil carbon stock in the organic layer, 0-10, and 10-20 cm mineral layers after 13 years of annual nitrogen additions $\left(0,3,6,12\right.$, and $\left.50 \mathrm{~kg} \mathrm{~N} \mathrm{ha}^{-1} \mathrm{y}^{-1}\right)$ in a Scots pine forest. Boxes display the median and one standard deviation above and below the median, and whiskers are the maximum and the minimum $(n=6)$. Boxes sharing letters within each soil layer are not significantly different at $p<0.05$ according to Tukey's test.

measurement occasion, all collars were measured at least twice within 3 days with the different subsample measurements at the same collar made at a different time of the day, such that collars measured early in the day during the first subsampling were measured later in the day during the second subsampling. We measured $\mathrm{CO}_{2}$ concentrations with Vaisala CARBOCAP GMP343 infrared gas analyzers mounted to portable plastic lids. Each lid had a small fan mounted on the underside to mix the chamber headspace gases during the measurement. After the lid was attached, the buildup of $\mathrm{CO}_{2}$ in the headspace was monitored for $180 \mathrm{~s}$, and the $\mathrm{CO}_{2}$ efflux was subsequently estimated using linear regression $\left(R^{2}>0.9\right)$.

\section{Statistical Analyses}

The effect of $\mathrm{N}$ on soil $\mathrm{C}$ stocks in each of the soil layers, annual soil C accumulation, litter inputs, and soil respiration per mass unit soil $\mathrm{C}$ was tested using analysis of variance, with $\mathrm{N}$ treatment (five levels) defined as a fixed factor and block $(n=6)$ as a random factor. Significant differences were then further explored using Tukey's honestly significant difference test. Before statistical testing, data were found to meet the assumptions of normality using the Shapiro-Wilk test and homoscedasticity using
Levene's test. The effect of $\mathrm{N}$, time (11 levels), and their interaction on areal soil respiration variables was analyzed using linear mixed effects models with block defined as random factor and using a first-order autoregressive covariance structure where the covariance decreases as the time between measurement increases (Legendre and Legendre 2012). Analyses were done in SPSS (Version 22, IBM Corp., Armonk, New York, USA), and effects were considered significant when $p<0.05$.

\section{RESUlts \\ Soil Carbon Stocks}

Nitrogen additions increased soil $\mathrm{C}$ stocks in the organic layer, but not in the mineral soil during the study period (Figure 1). The C stock in the organic layer of the $50 \mathrm{~N}$ treatment was $14.5 \mathrm{Mg} \mathrm{ha}^{-1}$, or $75 \%$ higher than in the control $(p<0.001)$, whereas the $\mathrm{C}$ stock in the $3 \mathrm{~N}, 6 \mathrm{~N}$, and $12 \mathrm{~N}$ treatments was not significantly different from the control. The annual $\mathrm{C}$ accumulation rate in the $50 \mathrm{~N}$ treatment during the 13 years of $\mathrm{N}$ addition was $1117 \mathrm{~kg} \mathrm{C}^{-1} \mathrm{yr}^{-1}$ higher than in the control treatment and had accumulated $22.3 \mathrm{~kg} \mathrm{C} \mathrm{kg}^{-1} \mathrm{~N}$ added (Figure 2A). 

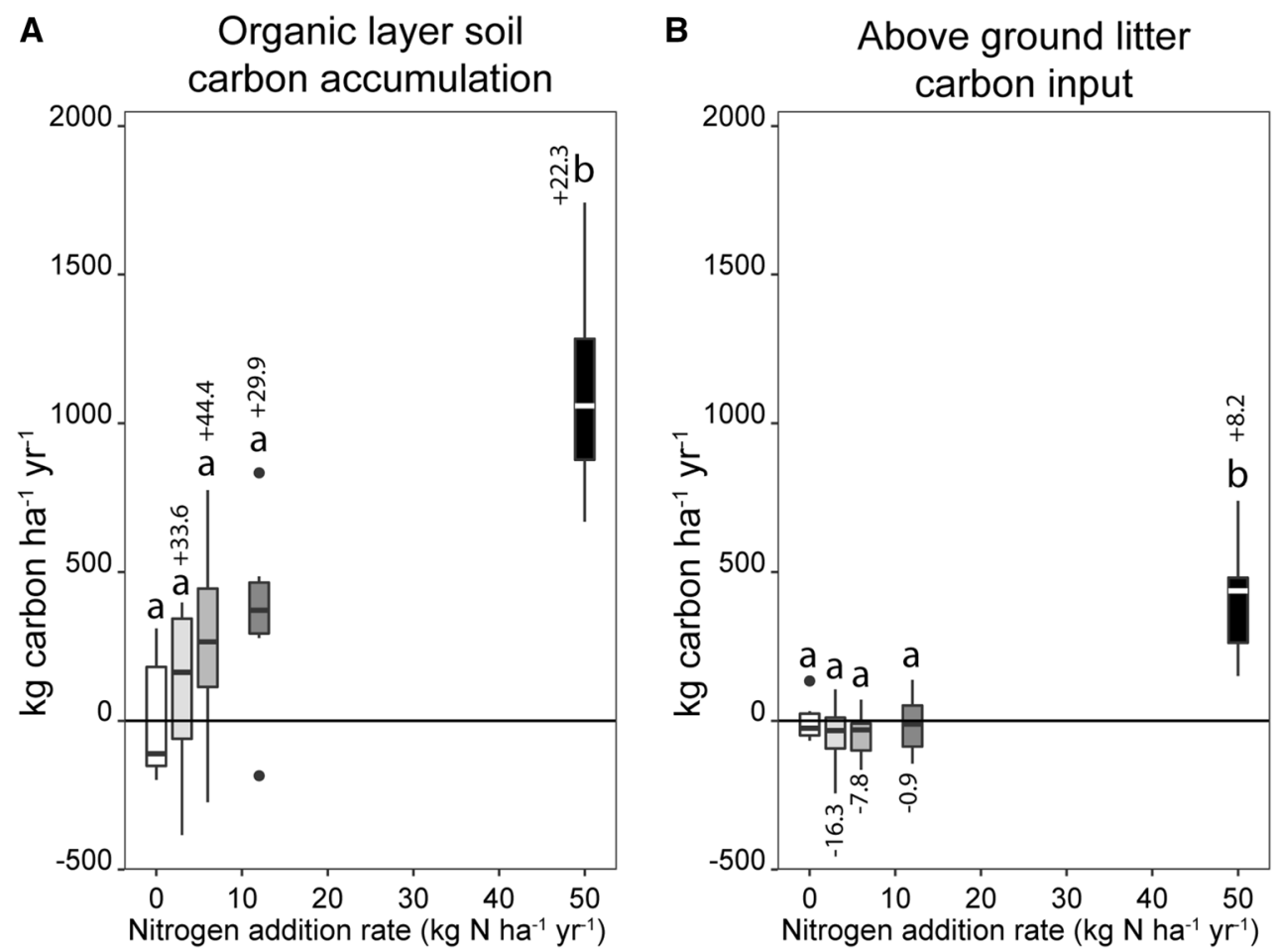

Figure 2. Annual carbon accumulation rate in the organic layer averaged over a 13 -year period (A) and annual aboveground litter carbon input averaged over the 12th and 13th year of annual nitrogen additions $(0,3$, 6, 12, and $50 \mathrm{~kg} \mathrm{~N} \mathrm{ha}{ }^{-1} \mathrm{y}^{-1}$ ). Values are relativized to the control treatment average, denoted with horizontal lines. The input of aboveground litter carbon was $890 \mathrm{~kg} \mathrm{ha}^{-1} \mathrm{y}^{-1}$ in the control treatment. Values above or below boxes represent average carbon flux per unit mass of nitrogen added $\left(\mathrm{kg} \mathrm{C} \mathrm{kg}^{-1} \mathrm{~N}\right.$ added). Boxes display the median and the quartile above and below the median and whiskers are the maximum and the minimum $(n=6)$. Outliers $(>1.5$ interquartile outside the box) are plotted individually. Boxes sharing letters within each panel are not significantly different at $p<0.05$ according to Tukey's test.

\section{Litter Input}

The litter input was $890 \mathrm{~kg} \mathrm{C} \mathrm{ha}^{-1} \mathrm{y}^{-1}$ in the control treatment, which significantly $(p<0.001)$ increased by $410 \mathrm{~kg} \mathrm{C} \mathrm{ha}^{-1} \mathrm{y}^{-1}$ in the $50 \mathrm{~N}$ treatment, which is equivalent to a $46 \%$ increase and an additional $\mathrm{C}$ input rate of $8.2 \mathrm{~kg} \mathrm{C} \mathrm{kg}^{-1} \mathrm{~N}$ added (Figure $2 \mathrm{~B}$ ). The lower $\mathrm{N}$ addition treatments did not affect litter input rates $(p>0.1)$.

\section{Soil Respiration}

Due to differences in soil $\mathrm{C}$ stocks between $\mathrm{N}$ addition treatments, the effect of $\mathrm{N}$ on soil respiration differed depending on whether it was expressed on a per unit area or per unit mass soil C (Figure 3A-D). Nitrogen had no significant effect on areal total respiration (Figure $3 \mathrm{~A}$, Table 2). However, when the total soil respiration was expressed on a per unit mass soil $\mathrm{C}$ basis, we found a significant decrease by $31.2 \%$ between the control and the $50 \mathrm{~N}$ treatment (Figure 3B). Nitrogen addition increased heterotrophic respiration sig- nificantly by $22.7,15.7$, and $22.0 \%$ in the $3 \mathrm{~N}$, $12 \mathrm{~N}$, and $50 \mathrm{~N}$ treatments relative to the control, respectively (Figure $3 \mathrm{C}$ ), while the $6 \mathrm{~N}$ treatment did not differ significantly from any of the other treatments. Expressed on a per mass unit soil C, the heterotrophic respiration was unaffected (Figure 3D). The autotrophic component was unresponsive to the $3 \mathrm{~N}, 6 \mathrm{~N}$, and $12 \mathrm{~N}$ treatments, whereas the $50 \mathrm{~N}$ treatment significantly decreased by $29.3 \%$ compared to the control (Figure 3E).

Total soil respiration varied seasonally with the highest recorded flux in August around day 220 both years (Figure 4A, B, $p<0.001$, Table 2). This seasonal variability was driven primarily by the autotrophic component that contributed $62 \%$ of the total soil respiration in the control treatment in August and then decreased to $48 \%$ in October (Figure 4C-F). In the $50 \mathrm{~N}$ treatment, the autotrophic component contributed $44 \%$ in August and decreased to $39 \%$ in October. The effect of $\mathrm{N}$ did, however, not change significantly over the season 
(Figure 4, Table 2, $p>0.05$ for the interaction terms).

\section{Discussion}

This study explores the effect of a gradient of simulated $\mathrm{N}$ deposition rates on soil $\mathrm{C}$ stocks in an $\mathrm{N}$ poor coniferous forest and evaluates three factors that may contribute to $\mathrm{C}$ stock changes, including litter input, autotrophic, and heterotrophic respiration. We found a significant increase in soil $\mathrm{C}$ stocks in the organic layer when $\mathrm{N}$ was added at a rate of $50 \mathrm{~kg} \mathrm{~N} \mathrm{ha}^{-1} \mathrm{y}^{-1}$ annually for 13 years, which is equivalent to a $\mathrm{C}$ accumulation rate of $22.3 \mathrm{~kg} \mathrm{C} \mathrm{kg}^{-1} \mathrm{~N}$ added. This response is twice as high as was reported in a nearby Norway spruce forest with similar $\mathrm{N}$ addition rates $\left(10 \mathrm{~kg} \mathrm{C} \mathrm{kg}^{-}\right.$ ${ }^{1} \mathrm{~N}$ ) (Maaroufi and others 2015) and three times higher than the average for $P$. sylvestris forests in Sweden and Finland $\left(7 \mathrm{~kg} \mathrm{C} \mathrm{kg}^{-1} \mathrm{~N}\right.$ ) (Hyvönen and others 2008), but similar to the average in a global meta-analysis of temperate forests (Janssens and others 2010) (19 kg C kg-1 N). Our site is a N poor (Table 1) and well-drained pine forest that experiences seasonal water limitation on net primary production (Palmroth and others 2014; Lim and others 2017). Despite this water limitation, the forest achieved a relatively high rate of soil $\mathrm{C}$ accumulation when enriched with high levels of $\mathrm{N}$ (Hyvönen and others 2008).

In agreement with our first hypothesis that a shift in C allocation between growth and autotrophic respiration would contribute to this response, we observed an increase in litter $\mathrm{C}$ inputs by $46 \%$ and a $29 \%$ decrease in autotrophic soil respiration in response to the $50 \mathrm{~N}$ treatment. Notably, this response only occurred at the highest $\mathrm{N}$ addition rate, whereas lower $\mathrm{N}$ addition rates had no effect on litter $\mathrm{C}$ inputs or on autotrophic respiration, which is consistent with the high potential for mosses (Gundale and others 2011), soil microbes (Kaye and Hart 1997), and abiotic sinks in the soil to immobilize $\mathrm{N}$ that reduces its availability to trees when input rates are relatively low (Templer and others 2012). The decrease in autotrophic respiration was highest in August when it contributed $62 \%$ of the total $\mathrm{CO}_{2}$ efflux in the control treatment, whereas it only contributed $44 \%$ of total respiration at the highest $\mathrm{N}$ addition rate (Figure 4). The peak in autotrophic respiration in $\mathrm{Au}-$ gust (Figure 4E, F) is consistent with studies that have shown trees exhibit a high rate of belowground $\mathrm{C}$ allocation late in the growing season (Pumpanen and others 2015) and the $\mathrm{N}$-induced reduction in autotrophic respiration is consistent with a reduction in the input of $\mathrm{C}$ via roots due to shift in allocation (Litton and others 2007). In addition to decreasing inputs of $\mathrm{C}$ via roots, autotrophic respiration could also decrease if $\mathrm{N}$ influences the relation between biomass production and respiration in the root zone (Chen and others 2014; Högberg and others 2002). We speculate that in addition to shifts in allocation between above and belowground structures, the decrease in autotrophic respiration could also be caused by changes in the allocation of $\mathrm{C}$ between root functions such as exudation and export into microbial communities in the root zone. These shifts could potentially impact priming effects (Kuzyakov, 2010) and the production of root biomass (Rasse and others 2005; Yuan and Chen 2012), which both are likely to impact soil C storage and could help explain the decrease in microbial biomass and decomposition observed in this (Maaroufi and others 2019) and many other $\mathrm{N}$ enrichment experiments (Knorr and others 2005; Treseder 2008).

We secondly hypothesized that soil microbial communities in this type of nutrient-poor coniferous forest are $\mathrm{N}$ limited and because of this that both heterotrophic and autotrophic respiration will increase at low $\mathrm{N}$ addition rates, whereas we hypothesized that high $\mathrm{N}$ addition rates would suppress their activities, as has been shown in many other studies (Janssens and others 2010; Knorr and others 2005; Treseder 2008). Our results revealed a generally positive effect of $\mathrm{N}$ additions on areal heterotrophic soil respiration (Figure 3C) at both high and low $\mathrm{N}$ addition rates, but not on autotrophic respiration (Figure 3E). The stimulating effect of $\mathrm{N}$ only appeared in the areal fluxes, and no significant effects appeared when we expressed the heterotrophic soil respiration per mass unit soil C (Figure 3D), indicating that most of the increase in areal heterotrophic respiration in this study was driven by the larger soil $\mathrm{C}$ stocks in the $\mathrm{N}$-treated plots, rather than alleviation of $\mathrm{N}$ limitation on saprotrophic communities. In contrast, some studies have observed increased decomposition (Knorr and others 2005) or respiration (Bowden and others 2004) after short term or low levels of $\mathrm{N}$ additions, which potentially could decrease soil C stocks (de Vries and others 2014). As one example from an experiment in a Scots pine forest $7 \mathrm{~km}$ from our experiment, Hasselquist and others (2012) detected a 50\% increase in total areal soil respiration after five years of annual $\mathrm{N}$ additions of $20 \mathrm{~kg} \mathrm{ha}^{-1} \mathrm{y}^{-1}$, whereas a much higher $\mathrm{N}$ addition rate of $100 \mathrm{~kg} \mathrm{~N} \mathrm{ha}^{-1} \mathrm{y}^{-1}$ over the same period had no effect. They attributed the increase to root and mycorrhizal respiration, that is, what we define 

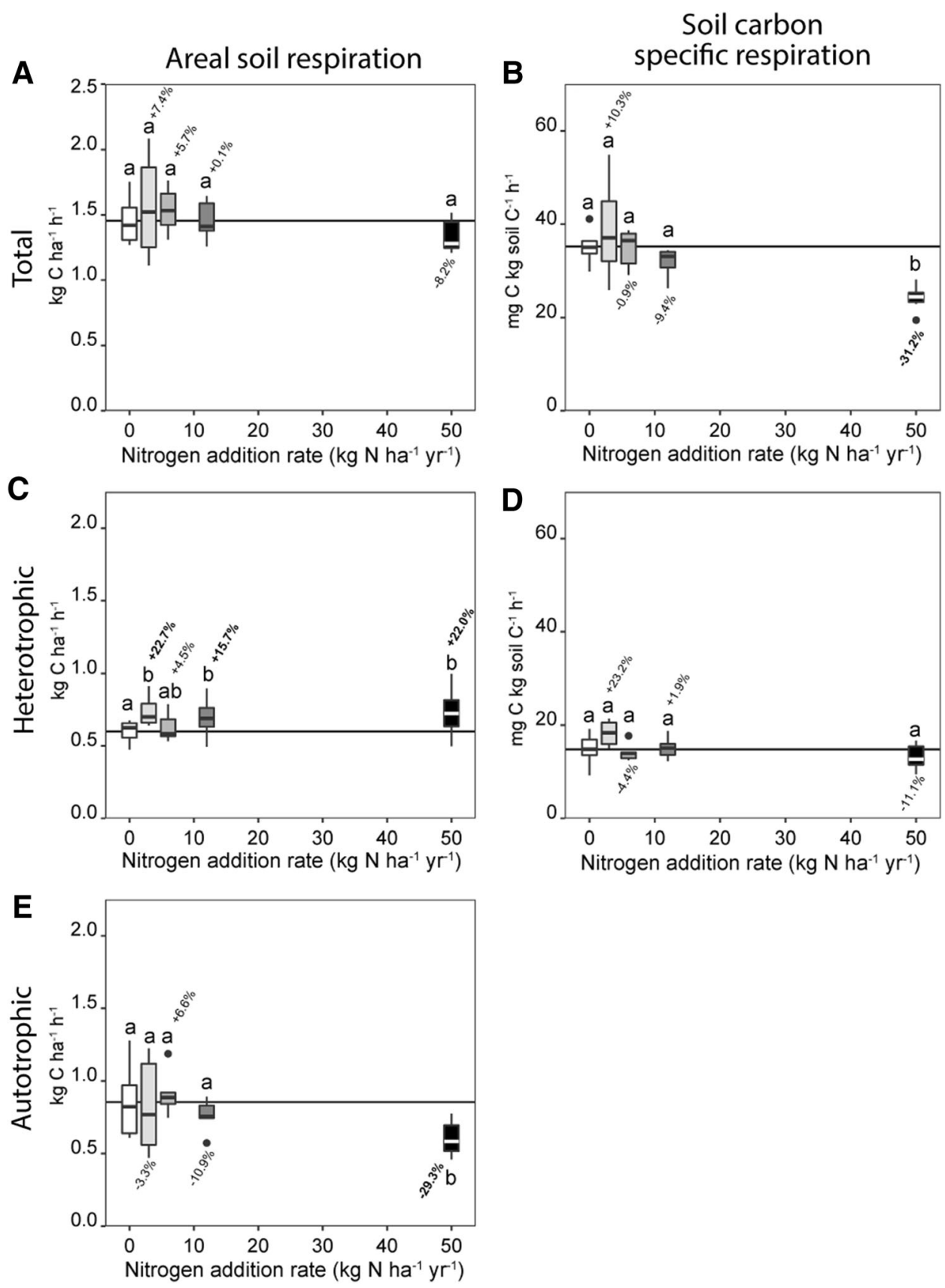

Figure 3. Soil respiration averaged for 11 measurement occasions during the growing season after $12-13$ years of annual nitrogen additions $\left(0,3,6,12\right.$, and $\left.50 \mathrm{~kg} \mathrm{~N} \mathrm{ha}^{-1} \mathrm{y}^{-1}\right)$. The total $(\mathbf{A}, \mathbf{B})$ and heterotrophic $(\mathbf{C}, \mathbf{D})$ respiration expressed on an area (left) and per mass unit carbon down to $20 \mathrm{~cm}$ in the soil (Figure 1) (right), and the difference in areal respiration between total $(\mathbf{A})$ and heterotrophic $(\mathbf{C})$ respiration, that is, autotrophic $(\mathbf{E})$. Boxes display the median and the quartile above and below the median and whiskers are the maximum and the minimum $(n=6)$. Outliers $(>1.5$ interquartile outside the box) are plotted individually. Boxes sharing letters within each panel are not significantly different at $p<0.05$ according to mixed effect models (areal respiration) or Tukey's test (soil carbon-specific respiration). Horizontal lines denote mean respiration in the control treatment, and values above or below boxes represent percentage difference in mean respiration compared to the control treatments. 
Table 2. The Effect of 12 to 13 Years of Annual Nitrogen Addition at 0, 3, 6, 12, and $50 \mathrm{~kg} \mathrm{~N} \mathrm{ha}^{-1} \mathrm{y}^{-1}$, Time (Repeated 11 Times Over Two Consecutive Growing Seasons), and their Interaction on Total Soil Respiration, and Divided into its Heterotrophic and Autotrophic Components as Analyzed by Mixed Effect Models, and the Effect of Nitrogen on Total and Heterotrophic Soil Respiration Expressed on a Per Unit Mass Soil Carbon, Analyzed with ANOVA.

\begin{tabular}{|c|c|c|c|}
\hline Source & Denominator DF & F-ratio & $p$ value \\
\hline \multicolumn{4}{|c|}{ Total areal respiration (LMM) } \\
\hline Nitrogen & 30.5 & 1.5 & 0.232 \\
\hline Time & 197 & 195.0 & $<0.001$ \\
\hline Nitrogen $\times$ time & 197 & 1.2 & 0.249 \\
\hline \multicolumn{4}{|c|}{ Heterotrophic areal respiration (LMM) } \\
\hline Nitrogen & 41.4 & 4.0 & 0.007 \\
\hline Time & 178 & 93.9 & $<0.001$ \\
\hline Nitrogen $\times$ time & 178 & 1.4 & 0.078 \\
\hline \multicolumn{4}{|c|}{ Autotrophic areal respiration (LMM) } \\
\hline Nitrogen & 38.3 & 3.8 & 0.011 \\
\hline Time & 182 & 48.6 & $<0.001$ \\
\hline Nitrogen $\times$ time & 182 & 1.2 & 0.173 \\
\hline \multicolumn{4}{|c|}{ Total soil carbon-specific respiration (ANOVA) } \\
\hline Nitrogen & 25 & 5.590 & 0.002 \\
\hline \multicolumn{4}{|c|}{ Heterotrophic soil carbon-specific respiration ANOVA) } \\
\hline Nitrogen & 25 & 1.936 & 0.07 \\
\hline
\end{tabular}

as autotrophic soil respiration. Similarly, Bidartondo and others (2001) detected an instant and strong increase in respiration in some species of mycorrhizal fungi but not others when $\mathrm{N}$ was added to conifer tree seedlings grown in mesocosms.

In contrast to these studies, our data do not show an increase in autotrophic respiration. It is possible that such effects occurred during earlier phases of our experiment, but have now diminished. However, we do not find any lasting signs of soil C losses in these treatments (Figure 2A), which higher respiration rates would likely have caused (de Vries and others 2014). The general decrease in soil respiration expressed on a per mass unit soil $C$ we observed supports the result of a parallel study in the same system focused on decomposition that found that $\mathrm{N}$ enrichment decreases the abundance of both fungal and most bacterial biomarkers, which corresponds with a reduced rate of litter decomposition (Maaroufi and others 2019). Taken together, the general decrease in soil respiration, markedly driven by reduced autotrophic respiration, along with reduction in microbial biomass, fungal community composition shifts, and reduced decomposition rates that we have shown in a previous studies (Maaroufi and others 2019), likely plays a major role in the accumulation of $\mathrm{C}$ observed in this and other $\mathrm{N}$ addition experiments.

Weighing the relative contribution of changes in $\mathrm{C}$ inputs via litter and output via soil respiration to the accumulation of soil $\mathrm{C}$ is challenging due to differences in temporal resolution, but can also provide mechanistic insights. The organic layer $\mathrm{C}$ stock in the $50 \mathrm{~N}$ treatment was $14.5 \mathrm{Mg} \mathrm{C} \mathrm{ha}^{-1}$ higher than the control treatment (Figure 1), and aboveground tree litter input at the forest floor was elevated by on average $410 \mathrm{~kg} \mathrm{C} \mathrm{ha}^{-1} \mathrm{y}^{-1}$ in this treatment, possibly adding $5330 \mathrm{~kg} \mathrm{C}^{-1}$ in total during the experiment (Figure $2 \mathrm{~B}$ ). This value is likely to be an accurate estimate of tree litter $\mathrm{C}$ input of the entire duration of the experiment, as the maximum growth response was attained at first in the seventh year of the experiment, and has since then declined (From and others 2016). However, it is possibly an overestimate of the total $C$ inputs, as litter from plant groups that often decline in response to $\mathrm{N}$, such as understory vegetation, is not included in our estimate (Maaroufi and others 2016). As an example, the moss layer in this experiment, dominated by Pleurozium schreberi (Brid.) Mitt., decreased by $795 \mathrm{~kg} \mathrm{C} \mathrm{ha}^{-1}$ during the first four years in the $50 \mathrm{~N}$ treatment, leading to 

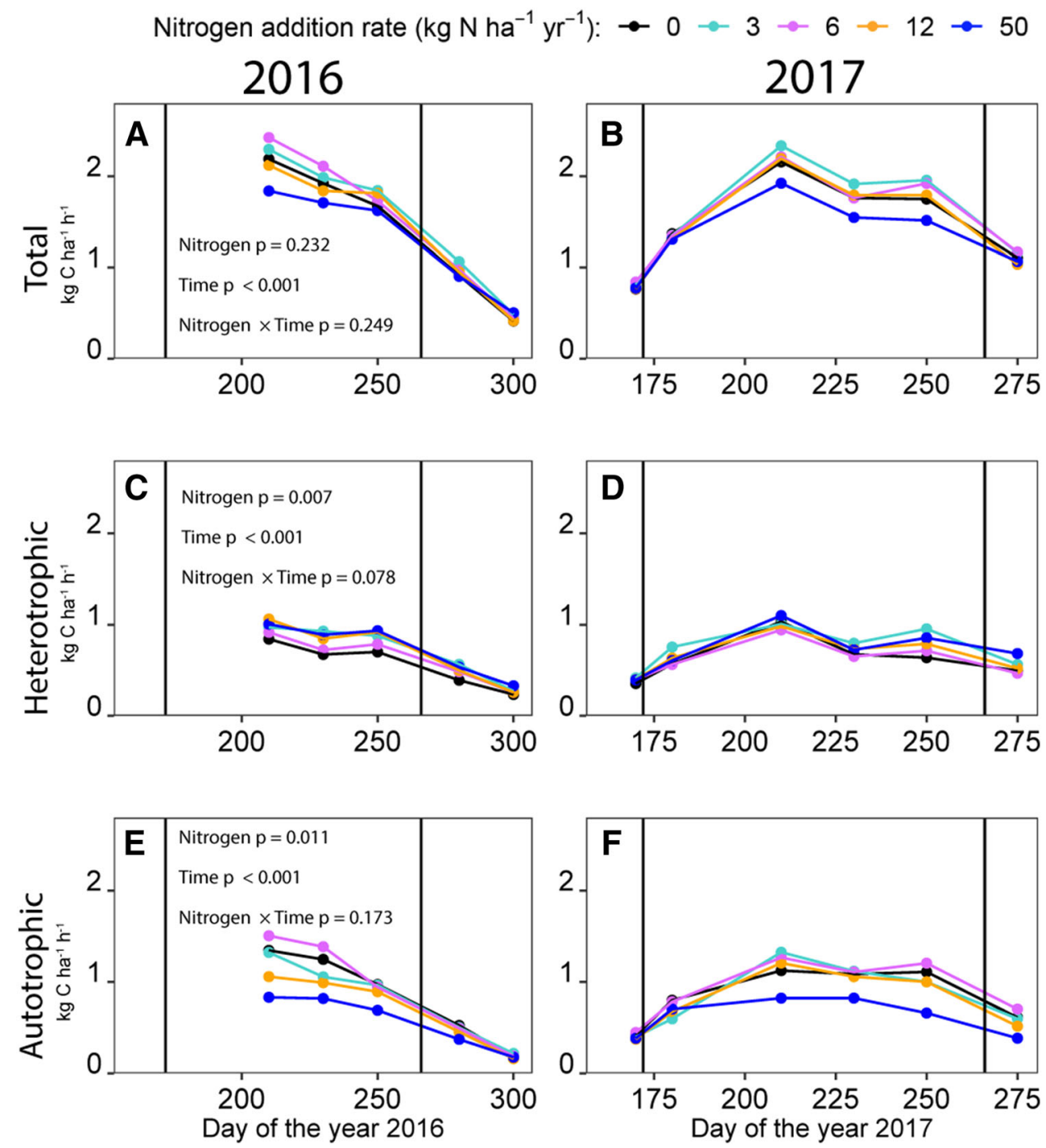

Figure 4. Total areal soil respiration $(\mathbf{A}, \mathbf{B})$ partitioned into its heterotrophic $(\mathbf{C}, \mathbf{D})$ and autotrophic components $(\mathbf{E}, \mathbf{F})$ over the growing season for five levels of nitrogen additions $\left(0,3,6,12\right.$, and $\left.50 \mathrm{~kg} \mathrm{~N} \mathrm{ha}^{-1} \mathrm{y}^{-1}\right)$ for 12 and 13 years in 2016 (left) and 2017 (right), respectively. Soil respiration was partitioned by removing tree roots (that is, trenching) in 2014 on permanent subplots. Vertical lines indicate the summer solstice and autumn equinox, respectively. $p$ values are the direct and interactive effects of nitrogen addition and time evaluated with mixed effect models (Table 2).

a small short-term flush of $C$ inputs, at the beginning of the experiment, but a loss of moss litter production during the rest of the experiment (Gundale and others 2011). Increased litter C inputs have therefore clearly contributed to the increase in organic layer C stocks in the $50 \mathrm{~N}$ treatment, but it is insufficient by itself to explain more than one-third of the difference in C stocks (Figure 2). This indicates that the various mechanisms that cause soil respiration (Figure 3) and decomposition (Maaroufi and others 2019) to decline are likely to be of relatively greater impor- tance in explaining why soil $\mathrm{C}$ stocks increase in response to high levels of $\mathrm{N}$ addition.

\section{Conclusions}

Our study provides rare experimental data describing how low versus high levels of $\mathrm{N}$ enrichment simulating atmospheric $\mathrm{N}$ deposition rates in northern coniferous forests impact soil C inputs and outputs, and changes to soil C stocks. One key finding of our study was that $\mathrm{C}$ accumulated in the organic layer, by an average of $22.3 \mathrm{~kg}$ 
$\mathrm{C} \mathrm{kg} \mathrm{N}^{-1}$ in the high $\mathrm{N}$ treatment $\left(50 \mathrm{~kg} \mathrm{ha}^{-1} \mathrm{y}^{-1}\right)$ averaged over the 13 years the experiment has run. This increase appears to be driven by both an increase in litter input and a decrease in autotrophic soil respiration. In contrast, lower $\mathrm{N}$ addition rates $\left(\leq 12 \mathrm{~kg} \mathrm{ha}^{-1} \mathrm{y}^{-1}\right)$ that are more representative of the range of atmospheric $\mathrm{N}$ deposition in northern coniferous forests did not stimulate aboveground litter production during the study period. Further, in contrast to our expectation that low levels of $\mathrm{N}$ would stimulate microbial activity, we found that neither heterotrophic nor autotrophic respiration was stimulated by our three lowest $\mathrm{N}$ treatments $\left(3,6\right.$, and $\left.12 \mathrm{~kg} \mathrm{~N} \mathrm{ha}^{-1} \mathrm{y}^{-1}\right)$ relative to the control. Our findings have substantial implications for potentially improving the way $\mathrm{N}$ deposition is represented in Earth systems models, which most commonly emphasize that $\mathrm{N}$ enhances soil C stocks by enhancing NPP and litter inputs (Parton and others 1993; Smith and others 2014; Thomas and others 2013, 2015). In contrast, our work clearly shows that litter inputs in northern forests can be relatively unresponsive to $\mathrm{N}$ at low addition rates and that changes in aboveground litter input only explain approximately one-third of the $\mathrm{C}$ that accumulates in the soil. Instead, decreased respiration is clearly a major factor contributing to the accumulation of $\mathrm{C}$ in the soil, and we suggest that shifts in $\mathrm{C}$ allocation between different plant functions above- and belowground, and within the root zone, play a pivotal role in the soil $\mathrm{C}$ dynamics in $\mathrm{N}$-enriched forest soils, where further research is needed.

\section{ACKNOWLEDGMENTS}

Open access funding provided by Swedish University of Agricultural Sciences. We thank the Swedish Infrastructure for Terrestrial Ecosystem Sciences (SITES) for providing the experiment and Viktor Boström, Dorothea Zannantonio, Jan Lindblad, Róbert Blaško, Felicia Lidman, and Tor Hansson Frank for assistance in the field. We also thank Sara Vicca at the University of Antwerp for providing soil data and two anonymous reviewers for valuable feedback on a previous version of this paper. The project was funded by the Swedish research council for environment, agricultural sciences, and spatial planning (FORMAS) and the Knut and Alice Wallenberg foundation.

\section{OPEN ACCESS}

This article is licensed under a Creative Commons Attribution 4.0 International License, which per- mits use, sharing, adaptation, distribution and reproduction in any medium or format, as long as you give appropriate credit to the original author(s) and the source, provide a link to the Creative Commons licence, and indicate if changes were made. The images or other third party material in this article are included in the article's Creative Commons licence, unless indicated otherwise in a credit line to the material. If material is not included in the article's Creative Commons licence and your intended use is not permitted by statutory regulation or exceeds the permitted use, you will need to obtain permission directly from the copyright holder. To view a copy of this licence, visit $h$ ttp://creativecommons.org/licenses/by/4.0/.

\section{DATA AVAILABILITY}

Data from this article can be found at: https://www. safedeposit.se/projects/199.

\section{REFERENCES}

Ågren GI, Hyvönen R, Berglund SL, Hobbie SE. 2013. Estimating the critical N:C from litter decomposition data and its relation to soil organic matter stoichiometry. Soil Biology and Biochemistry 67:312-18.

Bidartondo MI, Ek H, Wallander H, Söderström B. 2001. Do nutrient additions alter carbon sink strength of ectomycorrhizal fungi? New Phytologist 151:543-50.

Bonan GB. 1989. Environmental factors and ecological processes in boreal forests. Annual Review of Ecology and Systematics 20:1-28.

Bond-Lamberty B, Bronson D, Bladyka E, Gower ST. 2011. A comparison of trenched plot techniques for partitioning soil respiration. Soil Biology and Biochemistry 43:2108-14.

Bowden RD, Davidson E, Savage K, Arabia C, Steudler P. 2004. Chronic nitrogen additions reduce total soil respiration and microbial respiration in temperate forest soils at the Harvard Forest. Forest Ecology and Management 196:43-56.

Chen GS, Yang YS, Robinson D. 2014. Allometric constraints on, and trade-offs in, belowground carbon allocation and their control of soil respiration across global forest ecosystems. Global Change Biology 20:1674-84.

De Vries W. 2009. Assessment of the relative importance of nitrogen deposition and climate change on the sequestration of carbon by forests in Europe: an overview Introduction. Forest Ecology and Management 258:VII-X.

De Vries W, Du EZ, Butterbach-Bahl K. 2014. Short and longterm impacts of nitrogen deposition on carbon sequestration by forest ecosystems. Current Opinion in Environmental Sustainability 9-10:90-104.

De Vries W, Solberg S, Dobbertin M et al. 2008. Ecologically implausible carbon response? Nature 451:El-3.

Fog K. 1988. The effect of added nitrogen on the rate of decomposition of organic matter. Biol Rev Camb Philos Soc 63:433-62.

Franklin O, Näsholm T, Högberg P, Högberg MN. 2014. Forests trapped in nitrogen limitation-an ecological market per- 
spective on ectomycorrhizal symbiosis. New Phytologist 203:657-66

Fransson J (2017) Forest statistics 2017-Official Statistics of Sweden. In: Nilsson P, Cory N, Eds. Skogsdata. Umeå, Sweden, Department of Forest Resource Management-Swedish University of Agricultural Sciences. pp Page.

From F, Lundmark T, Mörling T, Pommerening A, Nordin A. 2016. Effects of simulated long-term $\mathrm{N}$ deposition on Picea abies and Pinus sylvestris growth in boreal forest. Canadian Journal of Forest Research 46:1396-403.

Galloway JN, Townsend AR, Erisman JW et al. 2008. Transformation of the nitrogen cycle: recent trends, questions, and potential solutions. Science 320:889-92.

Gundale MJ, Deluca TH, Nordin A. 2011. Bryophytes attenuate anthropogenic nitrogen inputs in boreal forests. Global Change Biology 17:2743-53.

Gundale MJ, From F, Bach LH, Nordin A. 2014. Anthropogenic nitrogen deposition in boreal forests has a minor impact on the global carbon cycle. Global Change Biology 20:276-86.

Hanson PJ, Edwards NT, Garten CT, Andrews JA. 2000. Separating root and soil microbial contributions to soil respiration: a review of methods and observations. Biogeochemistry 48:115-46.

Hasselquist NJ, Metcalfe DB, Högberg P. 2012. Contrasting effects of low and high nitrogen additions on soil $\mathrm{CO}_{2}$ flux components and ectomycorrhizal fungal sporocarp production in a boreal forest. Global Change Biology 18:3596-605.

Helmisaari H-S, Derome J, Nojd P, Kukkola M. 2007. Fine root biomass in relation to site and stand characteristics in Norway spruce and Scots pine stands. Tree Physiology 27:1493-504.

Hermans C, Hammond JP, White PJ, Verbruggen N. 2006. How do plants respond to nutrient shortage by biomass allocation? Trends in Plant Science 11:610-17.

Högberg P, Nordgren A, Ågren GI. 2002. Carbon allocation between tree root growth and root respiration in boreal pine forest. Oecologia 132:579-81.

Högberg P, Nordgren A, Buchmann N et al. 2001. Large-scale forest girdling shows that current photosynthesis drives soil respiration. Nature 41 1:789-92.

Holland EA, Braswell BH, Lamarque JF et al. 1997. Variations in the predicted spatial distribution of atmospheric nitrogen deposition and their impact on carbon uptake by terrestrial ecosystems. Journal of Geophysical Research-Atmospheres 102:15849-66.

Houle D, Moore JD. 2008. Soil solution, foliar concentrations and tree growth response to 3-year of ammonium-nitrate addition in two boreal forests of Quebec, Canada. Forest Ecology and Management 255:2049-60.

Hyvönen R, Persson T, Andersson S, Olsson B, Ågren GI, Linder S. 2008. Impact of long-term nitrogen addition on carbon stocks in trees and soils in northern Europe. Biogeochemistry 89:121-37.

Janssens IA, Dieleman W, Luyssaert S et al. 2010. Reduction of forest soil respiration in response to nitrogen deposition. Nature Geoscience 3:315-22.

Karlsson GP, Hellsten S, Karlsson PE, Akselsson C, Ferm M. 2012. Kvävedepositionen till Sverige-Jämförelse av depositionsdata från Krondroppsnätet, Luft- och nederbördskemiska nätet samt EMEP. pp Page, IVL Svenska Miljöinstitutet AB.

Kaye JP, Hart SC. 1997. Competition for nitrogen between plants and soil microorganisms. Trends in Ecology and Evolution 12:139-43.
Knorr M, Frey SD, Curtis PS. 2005. Nitrogen additions and litter decomposition: a meta-analysis. Ecology 86:3252-7.

Kuzyakov Y. 2010. Priming effects: interactions between living and dead organic matter. Soil Biology and Biochemistry 42:1363-71.

Kuzyakov Y, Xu XL. 2013. Competition between roots and microorganisms for nitrogen: mechanisms and ecological relevance. New Phytologist 198:656-69.

Lebauer DS, Treseder KK. 2008. Nitrogen limitation of net primary productivity in terrestrial ecosystems is globally distributed. Ecology 89:371-9.

Legendre P, Legendre L. 2012. Numerical Ecology. Vol. 24, 3rd edn. Elsevier.

Lim H, Oren R, Linder S et al. 2017. Annual climate variation modifies nitrogen induced carbon accumulation of Pinus sylvestris forests. Ecological Applications 27:1838-51. https://doi. org/10.1002/eap.1571.

Litton CM, Raich JW, Ryan MG. 2007. Carbon allocation in forest ecosystems. Global Change Biology 13:2089-109.

Maaroufi NI, Nordin A, Hasselquist NJ, Bach LH, Palmqvist K, Gundale MJ. 2015. Anthropogenic nitrogen deposition enhances carbon sequestration in boreal soils. Global Change Biology 21:3169-80.

Maaroufi NI, Nordin A, Palmqvist K, Gundale MJ. 2016. Chronic nitrogen deposition has a minor effect on the quantity and quality of aboveground litter in a boreal forest. PLOS ONE $11: \mathrm{e} 0162086$.

Maaroufi NI, Nordin A, Palmqvist K et al. 2019. Anthropogenic nitrogen enrichment enhances soil carbon accumulation by impacting saprotrophs rather than ectomycorrhizal fungal activity. Global Change Biology 25:9.

Magnani F, Mencuccini M, Borghetti M et al. 2007. The human footprint in the carbon cycle of temperate and boreal forests. Nature 447:848-51.

Mäkelä A, Valentine HT, Helmisaari H-S. 2008. Optimal co-allocation of carbon and nitrogen in a forest stand at steady state. New Phytologist 180:114-23.

Myneni RB, Dong J, Tucker CJ et al. 2001. A large carbon sink in the woody biomass of Northern forests. Proceedings of the National Academy of Sciences of the United States of America 98:14784-9.

Nohrstedt H-Ö. 2001. Response of coniferous forest ecosystems on mineral soils to nutrient additions: a review of Swedish experiences. Scandinavian Journal of Forest Research 16:555-73.

Olsson MT, Erlandsson M, Lundin L, Nilsson T, Nilsson A, Stendahl J. 2009. Organic carbon stocks in Swedish podzol soils in relation to soil hydrology and other site characteristics. Silva Fennica 43:209-22.

Palmroth S, Bach LH, Nordin A, Palmqvist K. 2014. Nitrogenaddition effects on leaf traits and photosynthetic carbon gain of boreal forest understory shrubs. Oecologia 175:457-470. h ttps://doi.org/10.1007/s00442-014-2923-9.

Parton WJ, Scurlock JMO, Ojima DS et al. 1993. Observations and modeling of biomass and soil organic-matter dynamics for the grassland biome worldwide. Global Biogeochemical Cycles 7:785-809.

Peng Y, Li F, Zhou G et al. 2017. Nonlinear response of soil respiration to increasing nitrogen additions in a Tibetan alpine steppe. Environmental Research Letters 12:024018.

Persson O, Harrison K, Bauer C, Coûteaux D, Högberg K, Matteucci R, Schulze P (2000) Experimental sites in the NIPHYS/ CANIF project. In: Schulze ED, Ed. Ecological studies. pp Page. 
Pumpanen J, Kolari P, Ilvesniemi H et al. 2004. Comparison of different chamber techniques for measuring soil $\mathrm{CO}_{2}$ efflux. Agricultural and Forest Meteorology 123:159-76.

Pumpanen J, Kulmala L, Linden A, Kolari P, Nikinmaa E, Hari P. 2015. Seasonal dynamics of autotrophic respiration in boreal forest soil estimated by continuous chamber measurements. Boreal Environment Research 20:637-50.

Rasse DP, Rumpel C, Dignac MF. 2005. Is soil carbon mostly root carbon? Mechanisms for a specific stabilisation. Plant and Soil 269:341-56.

Reay DS, Dentener F, Smith P, Grace J, Feely RA. 2008. Global nitrogen deposition and carbon sinks. Nature Geoscience $1: 430-7$.

Sandström F, Petersson H, Kruys N, Ståhl G. 2007. Biomass conversion factors (density and carbon concentration) by decay classes for dead wood of Pinus sylvestris, Picea abies and Betula spp. in boreal forests of Sweden. Forest Ecology and Management 243:19-27.

Scarascia-Mugnozza G, Bauer GA, Persson H, Matteucci G, Masci A. 2000. Tree Biomass, Growth and Nutrient Pools. In: Schulze E-D, Ed. Carbon and nitrogen cycling in European forest ecosystems. Berlin: Springer.

Smith B, Warlind D, Arneth A, Hickler T, Leadley P, Siltberg J, Zaehle S. 2014. Implications of incorporating N cycling and N limitations on primary production in an individual-based dynamic vegetation model. Biogeosciences 11:2027-54.

Strengbom J, Nordin A, Näsholm T, Ericson L. 2002. Parasitic fungus mediates change in nitrogen-exposed boreal forest vegetation. Journal of Ecology 90:61-7.

Stuiver BM, Gundale MJ, Wardle DA, Nilsson MC. 2015. Nitrogen fixation rates associated with the feather mosses Pleurozium schreberi and Hylocomium splendens during forest stand development following clear-cutting. Forest Ecology and Management 347:130-9.
Talbot JM, Allison SD, Treseder KK. 2008. Decomposers in disguise: mycorrhizal fungi as regulators of soil $\mathrm{C}$ dynamics in ecosystems under global change. Functional Ecology 22:95563.

Tamm CO. 1991. Nitrogen in terrestrial ecosystems: questions of productivity, vegetational changes, and ecosystem stability. Berlin: Springer.

Templer PH, Mack MC, Chapin FS et al. 2012. Sinks for nitrogen inputs in terrestrial ecosystems: a meta-analysis of $\mathrm{N}-15$ tracer field studies. Ecology 93:1816-29.

Thomas RQ, Brookshire ENJ, Gerber S. 2015. Nitrogen limitation on land: how can it occur in Earth system models? Global Change Biology 21:1777-93.

Thomas RQ, Zaehle S, Templer PH, Goodale CL. 2013. Global patterns of nitrogen limitation: confronting two global biogeochemical models with observations. Global Change Biology 19:2986-98.

Treseder KK. 2008. Nitrogen additions and microbial biomass: a meta-analysis of ecosystem studies. Ecology Letters 11:111120.

Ukonmaanaho L, Pitman R, Bastrup-Birk A, Breda N, Rautio P. 2016. Part XIII: Sampling and Analysis of Litterfall, Thünen Institute for Forests Ecosystems, Eberswalde, Germany, United nations economic commission for Europe.

Vicca S, Luyssaert S, Penuelas J et al. 2012. Fertile forests produce biomass more efficiently. Ecology Letters 15:520-6.

Vitousek PM, Aber JD, Howarth RW et al. 1997. Human alteration of the global nitrogen cycle: sources and consequences. Ecological Applications 7:737-49.

Yuan ZY, Chen HYH. 2012. A global analysis of fine root production as affected by soil nitrogen and phosphorus. Proceedings of the Royal Society Biological Sciences 279:3796802 . 